\title{
Spatio-Temporal Patterns of Joshua Tree Stand Structure and Regeneration Following Mojave Desert Wildfires
}

\section{OPEN ACCESS}

Edited by:

Eddie John Van Etten, Edith Cowan University, Australia

Reviewed by:

Lynn Sweet,

University of California, Riverside,

United States

Daniel Moya,

University of Castilla-La Mancha,

Spain

*Correspondence:

Samuel B. St. Clair

stclair@byu.edu

orcid.org/000-0001-6612-0329

Specialty section:

This article was submitted to Biogeography and Macroecology, a section of the journal

Frontiers in Ecology and Evolution

Received: 14 February 2021

Accepted: 09 December 2021

Published: 27 January 2022

Citation:

St. Clair SB, St. Clair EA and St. Clair SB (2022) Spatio-Temporal

Patterns of Joshua Tree Stand Structure and Regeneration Following

Mojave Desert Wildfires.

Front. Ecol. Evol. 9:667635. doi: $10.3389 /$ fevo.2021.667635

\author{
Seth B. St. Clair, Elijah A. St. Clair and Samuel B. St. Clair* \\ Department of Plant and Wildlife Sciences, Brigham Young University, Provo, UT, United States
}

Eastern Joshua tree (Yucca jaegeriana) plays a central role in the ecology of the Mojave Desert ecosystem. However, the emergence of invasive grass fire-cycles in the last several decades brings into question Joshua trees' tolerance and resilience to changing fire regimes. This study's objective was to examine the effects of wildfires on the structure and regeneration potential of Joshua trees forests. We examined the density, size class structure, and regeneration response of Joshua tree populations on a network of one kilometer transects along the boundaries of four independent wildfires and the interior of the largest fire that occurred 15 years ago (2005) in the northeast Mojave Desert. Burned edge and burned interior transects had 23- and 4.1-fold lower Joshua tree stand densities than unburned transects. The more robust recovery of stand density along burned interior transects compared to burned edge transects appears to be primarily driven by more prolific vegetative sprouting. Our data show that Joshua trees can sprout vegetatively following fire, but it is not a strong or consistent post-fire resprouter. Limiting the spread of invasive annual grasses and novel fire regimes will be critical to maintaining healthy Joshua tree populations into the future, particularly on the edge of its ecological range.

Keywords: invasive grass fire cycle, Mojave Desert, vegetative regeneration, wildfire, Yucca brefifolia

\section{INTRODUCTION}

Wildfire activity is changing across earth's ecosystems due to human activity resulting in novel fire regimes that can have lasting effects on vegetation (Bowman et al., 2009; Crotteau et al., 2013). Wildfires are increasing in deserts of North America, primarily driven by invasive grass fire cycles (Brooks et al., 2004; Balch et al., 2013). Red brome (Bromus rubens L.), an invasive annual grass, has played a significant role in increasing fire activity in the Mojave Desert by increasing plant fuels' continuity and flammability upon drying at the end of the growing season (Brooks and Matchett, 2006). Fire risk is especially high in years with early fall precipitation and warm winter temperatures that produces longer growing seasons that fuel red brome growth (Horn et al., 2015; Horn and St. Clair, 2017). There is concern that increasing fire activity in North American deserts may favor the establishment and spread of exotic alien species to the exclusion of the native plant communities (Klinger and Brooks, 2017).

Desert wildfires alter desert plant community composition and function and strongly influence plant community succession (Horn et al., 2015). Plant community recovery following fire varies dramatically between sites depending on a variety of variables, including pre-fire vegetation 
composition and structure (Minnich, 1995), fire frequency and severity (Klinger and Brooks, 2017), post-fire climate conditions (DeFalco et al., 2010), and patterns of pollination, seed fate, and herbivory in burned desert landscapes (Bowman et al., 2017; Lybbert and St Clair, 2017). Fire chronosequence studies show a high degree of variability in plant communities' response in postfire environments (Minnich, 1995; Abella, 2009). The biggest concern related to novel fire regimes in deserts is the potential for state and transition changes due to positive responses of invasive annual grasses to post-fire conditions shortening fire return intervals so that native vegetation has little time to recover (Horn and St. Clair, 2017). Recent evidence suggests that both increasing fire frequency and higher burn severity can lead to pathways of dominance by invasive annual grasses and poor post-fire recovery of native vegetation (Klinger and Brooks, 2017).

Successful post-fire re-establishment of native vegetation depends on species resilience to fire primarily driven by fire tolerance and regeneration characteristics (Shryock et al., 2014). Abella (2010) summarized categories of major perennial species that tend to decrease or increase following fire based on these characteristics. At lower burn severity, desert succulents with high water content tend to be less vulnerable to burning, while two dominant Mojave species, Larrea tridentata and Yucca jaegeriana may escape because of their taller stature (Minnich, 1995). In contrast, annual and perennial grasses, forbs, and drought-deciduous shrubs still tend to be vulnerable to lower severity ground fire because of their short stature and low water content (Minnich, 1995). High burn severity driven by large woody fuel loads connected by continuous fine fuels can result in greater than 80\% losses in plant cover (Minnich, 1995; Abella, 2009; Lybbert et al., 2017). A variety of perennial desert shrubs and grasses show the ability to sprout from surviving roots after fire (Abella, 2010). Desert plants that survive or resprout following fire have shown significantly higher flower and seed production (Lybbert et al., 2017; Molinari et al., 2019), but environmental constraints in post-fire environments may limit plant recruitment from seed (Bryant et al., 2012; Bowman et al., 2017). More research is needed on how seed banks influence post-fire plant community succession (Abella et al., 2013).

Eastern Joshua tree (Yucca jaegeriana) (Lenz, 2007) is a semi-succulent, arborescent that can exceed $5 \mathrm{~m}$ in height and 300 years in age (Gilliland et al., 2006). Few studies have examined the post-fire ecology of Joshua trees. This is surprising considering Joshua trees' central role in the Mojave Desert ecosystem and the dramatic increase in Mojave Desert wildfire in recent decades. Joshua trees can regenerate vegetatively following fire (Loik et al., 2000; Abella, 2010) but are classified as having limited post-fire regeneration potential (Abella, 2009; Shryock et al., 2014). Furthermore, woody shrubs facilitate Joshua tree seedling establishment (Brittingham and Walker, 2000), so reducing shrub cover following fire would impose additional limitations on Joshua tree regeneration. What is more poorly known are spatial patterns of Joshua tree regeneration as a function of distance from burn boundaries where there may be variation in burn effects or differences in the biological community's characteristics. In other forest systems edge effects are known to strongly influence seedling establishment and patterns of recruitment (Montoro Girona et al., 2018; Martin et al., 2020).

Joshua tree forests are common in the northeast Mojave Desert, where fires related to red brome invasion are becoming larger and more frequent (Horn and St. Clair, 2017). Several large and independent fires that occurred in the summer of 2005 in the northeast Mojave provided an opportunity to assess Joshua trees' regeneration in post-fire environments. This study's objective was to characterize the post-fire structure and regeneration of Joshua tree stands 15 years after the 2005 wildfires. We addressed the following questions: (1) What are the characteristics of Joshua tree stands 15 years after wildfire occurrence? (2) Is there evidence of post-fire Joshua tree regeneration, and does it vary spatially between burned edges along fire boundaries to locations deeper into the fire's interior? We hypothesized greater Joshua tree regeneration along burned edges due to higher seed dispersal from adjacent unburned vegetation and lower burn severity.

\section{MATERIALS AND METHODS}

\section{Study Area}

This study was conducted in the Beaver Dam Wash of southwestern Utah in May 2020. The study area is characterized by native shrubs of which Coleogyne ramosissima Torr., Larrea tridentata (DC.) Coville, and Ambrosia dumosa (A. Gray) Payne

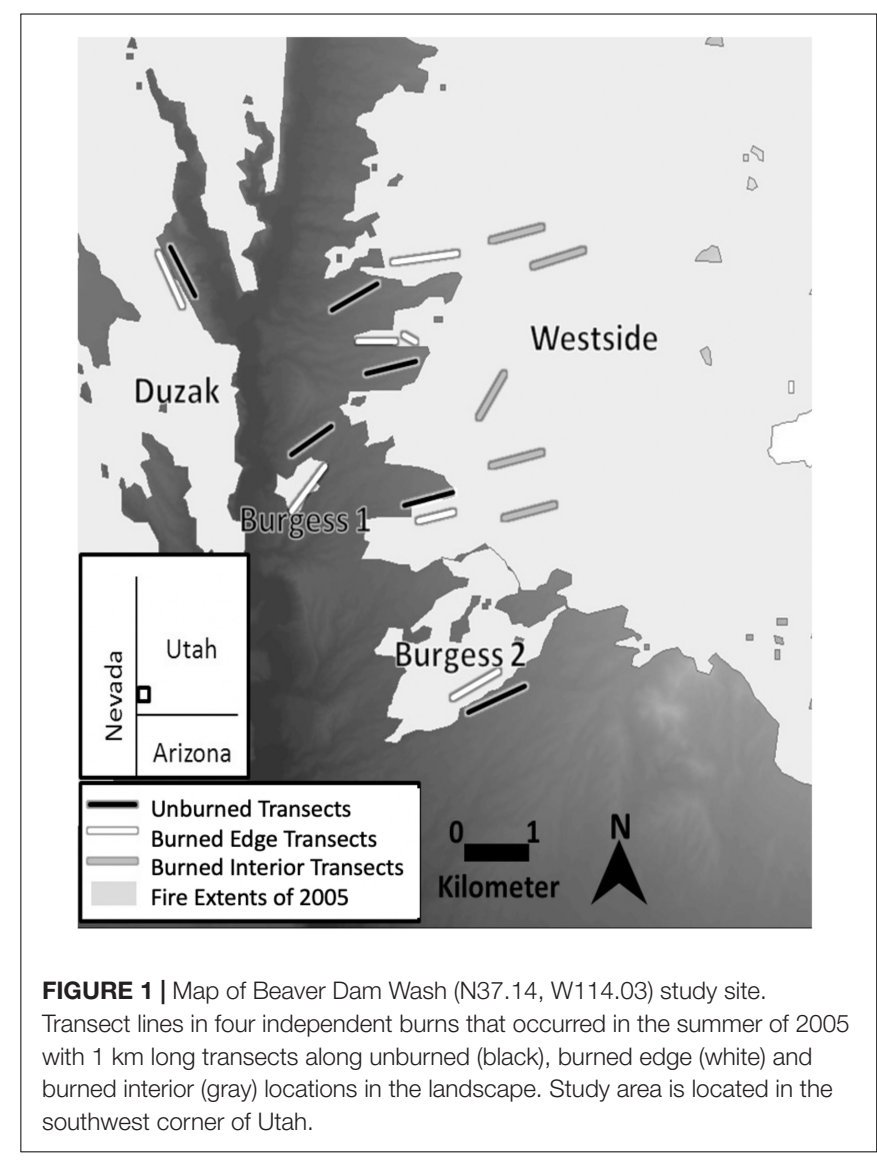


are the most common. Two yucca species are common in the study area Yucca baccata Torr. and Yucca jaegeriana. Common native herbaceous plants included Sphaeralcea ambigua A.Gray spp., Baileya multiradiata Harv. \& A. Gray, Astragalus nuttaliianus DC., Plantago spp. (P. patagonica and P. ovata), and Descurainia pinnata (Walter) Britton. Soil in the area is classified as a gravelly sandy loam (Soil Survey Staff, 2015). Mean annual precipitation is $272 \mathrm{~mm}$ and mean annual temperature is $16^{\circ} \mathrm{C}$ (Western Regional Climate Center, 2000). In recent years the landscape has been altered by plant invasions resulting in changing fire regimes characterized by larger and more frequent fires in the Mojave Desert (Brooks et al., 2004; Brooks and Matchett, 2006; Horn and St. Clair, 2017). Invasive annual grasses, Schismus arabicus Nees., and Bromus rubens L. responded positively to early fall precipitation in 2004 resulted in the build-up of fine fuels that triggered multiple, large-scale fires in the study area (Beaver Dam Wash) in the summer of 2005 (Horn and St. Clair, 2017). Burn transects were placed within four independent fires that occurred during the summer of 2005: Westside (June, 27,059 ha), Duzak (July, 7,065 ha-within Utah), Burgess 1 (July, 60 ha), and Burgess 2 (July, 712 ha) (Utah Bureau of Land Management).

\section{Study Design}

We established a network of $1 \mathrm{~km}$ long paired transect lines. Six transect pairs were positioned along adjacent burned/unburned boundaries within the four independent fires in 2005 (Figure 1). Paired transects were placed in areas where they would be adjacent to one another within $200 \mathrm{~m}$ on either side of a burn boundary. For the three transects pairs in the Westside fire we added an additional criterion of spreading them as far apart as possible to get broader coverage of the burned area. A single transect pair was placed in the Burgess 1, Burgess 2, and Duzak fires to get statistical replication in independent fires. The remaining three transects were spread across the Westside fire which was fourfold larger than the Duzak fire and several orders of magnitude larger than the Burgess 1 and 2 fires making up the majority of the area burned during the 2005 fires. Five additional transects were established in the interior of the Westside fire to compare Joshua tree regeneration responses in the interior of burned landscapes compared to adjacent burned edges. All transect pairs were selected on these criteria using GIS mapping software to prevent any bias from choosing sites while on location. We estimated pre-fire Joshua tree stand densities along burned-edge and burned-interior transects by counting the number of Joshua trees in a $100 \mathrm{~m}^{-2}$ square area in the center of each transect. Density counts were generated from 2004 image layers of the study area using Google Earth Pro. There were no differences in pre-fire stand density between burnededge and burned-interior transects $(P=0.71)$ or burn severity (Lybbert et al., 2017).

\section{Measurements}

At each 100-increment point along the transect, we measured the distances to the two nearest living Joshua trees on each side of the transect tape to estimate population density. This included surviving trees that had burned partially in the 2005 fires but still had living branches. On each of the trees (20 trees/transect), we measured tree height and trunk diameter. For Joshua trees under $1 \mathrm{~m}$ in height that would likely have regenerated after the fire based on sprout growth estimates (Keith, 1982), we measured the distance to the nearest dead Joshua tree. Tree height was determined using a telescoping meter stick. Trunk diameter was measured $20 \mathrm{~cm}$ above the soil surface using tree calipers.

\section{Statistical Analysis}

Mixed-effects linear models were used to examine the effects of burn condition and location (unburned, burned edge, burned interior) on Joshua tree stand density, tree height, trunk diameter, and percent of sprouts next to dead Joshua trees. In our mixed models, transect type (unburned, burned-edge, burnedinterior) and height class were specified as a fixed effect, and site (transect number) was specified as a random effect.

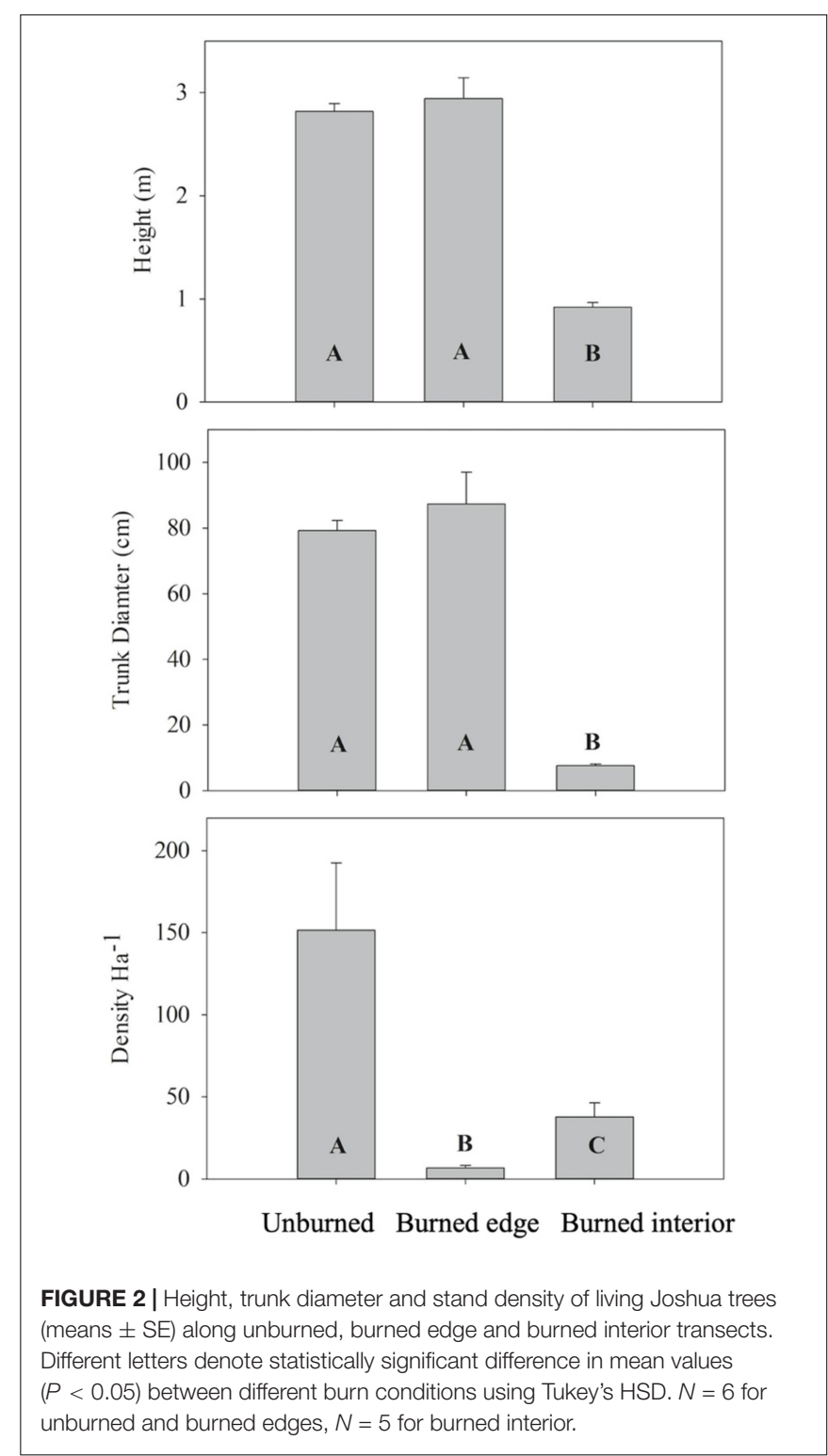


Tukey's LSD was used to test mean differences across burn conditions within each height class. Assumptions of normality and homoscedasticity were visually inspected using residual plots (e.g., histogram, scatterplot, and qqnorm of residuals). To meet equal variance assumptions, data were log-transformed when appropriate. All calculations, models, assumption analyses, and statistical significance determinations were performed using JMP statistical software (version 15).

\section{RESULTS}

The average stand density, height, and stem diameter varied significantly between Joshua trees growing along burned interior transects compared to unburned and burned edge transects. Joshua tree stand density was dramatically lower along burned edge (23-fold) and burned interior transects (4.1-fold) compared to unburned transects $(P<0.0001)$ (Figure 2$)$. Stand density was sixfold greater along burned interior transects compared to burned edge transects. The average height and trunk diameter of Joshua trees along burned interior transects were approximately 3.2- and 11-fold lower than the height and diameter averages of Joshua tree stands along burned edge and unburned transects $(P<0.0001)$ (Figure 2).

Height class distribution varied dramatically between Joshua trees growing along burned interior transects compared to unburned and burned edge transects. Nearly $80 \%$ of Joshua trees growing along burned interior transects were less than a meter tall, compared to less than $15 \%$ in the same height class for unburned and burned edge transects $(P<0.0001)$ (Figure 3). There was no statistical difference in the proportion of Joshua trees in the 1-2 $\mathrm{m}$ height class among the three transect types $(P=0.13)$. Unburned and burned edge transects had approximately 6-, 21-, and 5-fold higher proportions of Joshua trees in the 2-3, 3-4, and 4-5 $\mathrm{m}$ height classes compared to burned interior transects $(P<0.0001)$ (Figure 3). The majority of Joshua trees growing along burned edge and unburned transects were in the 1-4 $\mathrm{m}$ height range, with the largest proportion (near $40 \%$ ) in the 3-4 m height class (Figure 3).

There was evidence of vegetative regeneration through root sprouting of Joshua trees, particularly along burned interior transects. Nearly $75 \%$ of Joshua trees ( $<1 \mathrm{~m}$ tall) growing along burned interior transects were growing from the base of dead Joshua trees compared to $33 \%$ of trees ( $<1 \mathrm{~m}$ tall) next to the base of dead Joshua trees along burned edge transects $(P=0.0005)$ (Figure 4). We did not find any young Joshua trees growing in proximity to dead Joshua trees along unburned transects.

\section{DISCUSSION}

Our results provide evidence that Joshua tree forests exhibit significant changes in stand structure in post-fire environments depending on fire effects and regeneration responses. Reductions in stand density along burn transects were expected due to fire effects, but contrary to our hypothesis we found four-fold greater Joshua tree density along burned interior transects compared to burned edge transects (Figure 2). Minnich (1995) suggested

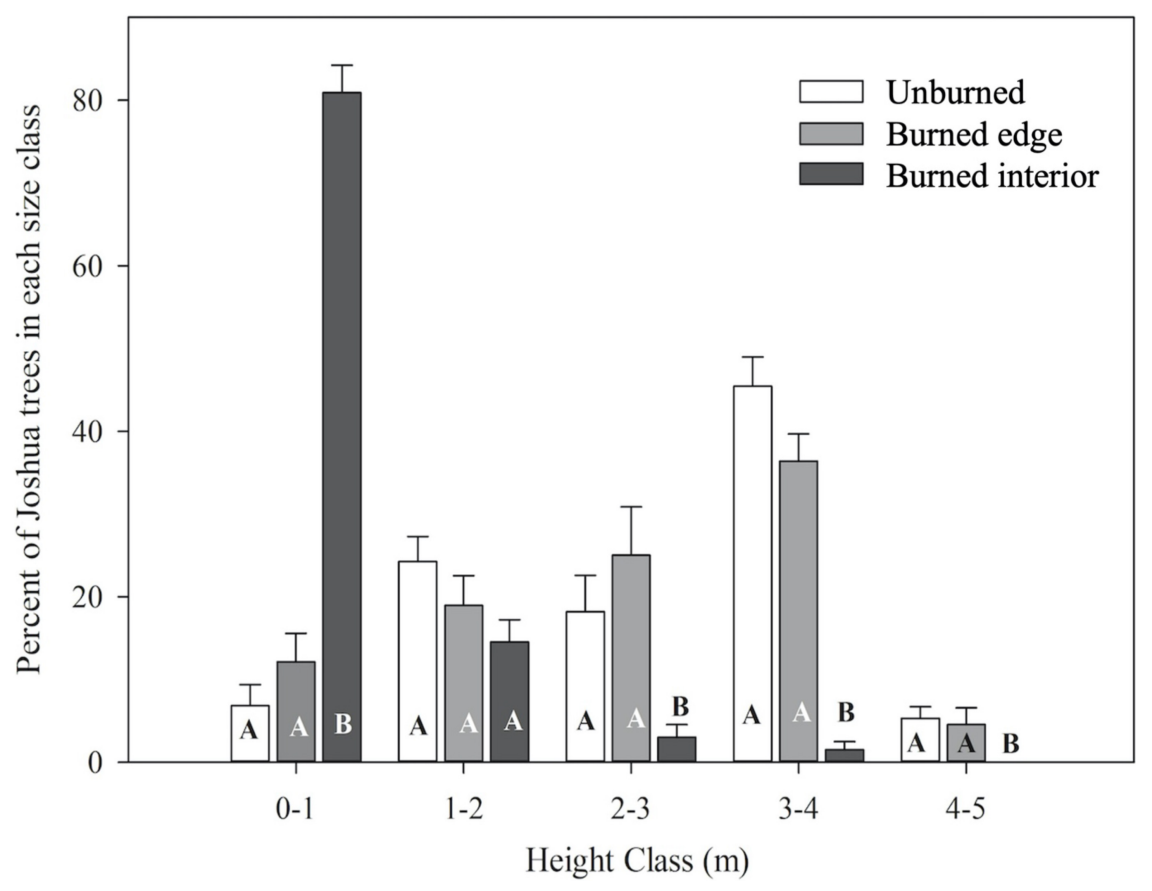

FIGURE 3 | Tree height distribution (means \pm SE) of living Joshua trees along unburned, burned edge and burned interior transects. Different letters denote statistically significant difference in mean values $(P<0.05)$ between different burn conditions within each height class using Tukey's HSD. $N=6$ for unburned and burned edges, $N=5$ for burned interior. 


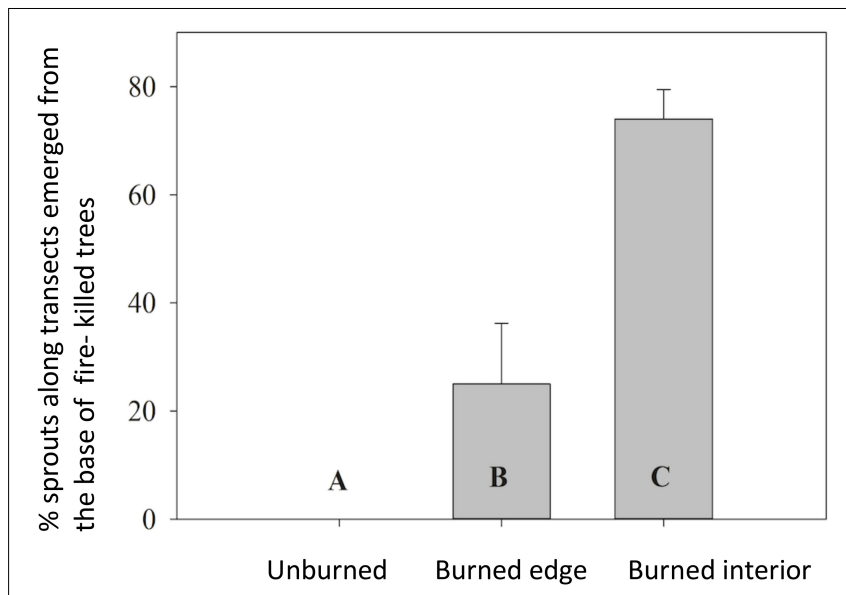

FIGURE 4 | Percent of Joshua tree sprouts ( $<1 \mathrm{~m}$ tall) along transect lines emerged from the base of a burned standing dead or fallen Joshua tree that died in the 2005 fire along unburned, burned edge and burned interior transects (means $\pm \mathrm{SE}$ ). Different letters denote statistically significant difference in mean values $(P<0.05)$ using Tukey's HSD.

that Joshua tree's higher vegetative regeneration could be related to lower burn severity. However, vegetation surveys of post-fire plant community cover and density showed similar burn severity in the burned, interior locations compared to burned edges in an earlier study along these same study transects (Lybbert and St Clair, 2017). Instead, it appears that increases in stands density in burned interiors is driven by significantly higher postfire sprouting based on our size class analysis (Figure 3). This is further supported by the significantly shorter and smaller diameter stand structure of Joshua trees growing along burned interior transects (Figure 2).

Joshua trees have been shown to sprout from the root crown of burned Joshua trees the year following a fire (Loik et al., 2000). Joshua trees' average height along burned interior transects was just under $100 \mathrm{~cm}$ (Figure 2) due to the high proportion of sprouts less than $1 \mathrm{~m}$ tall (Figure 3). Growth rates of 3.1$3.8 \mathrm{~cm} /$ year have been estimated for regenerating Eastern Joshua tree (Gilliland et al., 2006; Esque et al., 2015). Over the 15 years since the fire, this would have resulted in approximately 47$57 \mathrm{~cm}$ of vertical growth. This suggests that Joshua trees under 1 meter in height common in the burned interior transects were established soon after the 2005 fires.

There is evidence in the literature of up to $30 \%$ of burned Joshua trees resprouting after fire (Loik et al., 2000). Other studies tend to show significantly less post-fire Joshua tree regeneration (Minnich, 1995; Abella, 2010), which may represent differences in post-fire sprouting responses of the Eastern Joshua tree (Yucca jaegeriana) compared to the Western Joshua tree (Yucca brevifolia). Our study similarly shows a wide range of regeneration responses within a burned desert landscape. In our study, the high proportion of young Joshua trees regenerating in burned interior locations (Figure 4) appears to be driven by vegetative sprouting from the base of Joshua trees that burned in the 2005 fire (Figure 5). It is unclear why Joshua tree sprouting would have been higher along interior transects

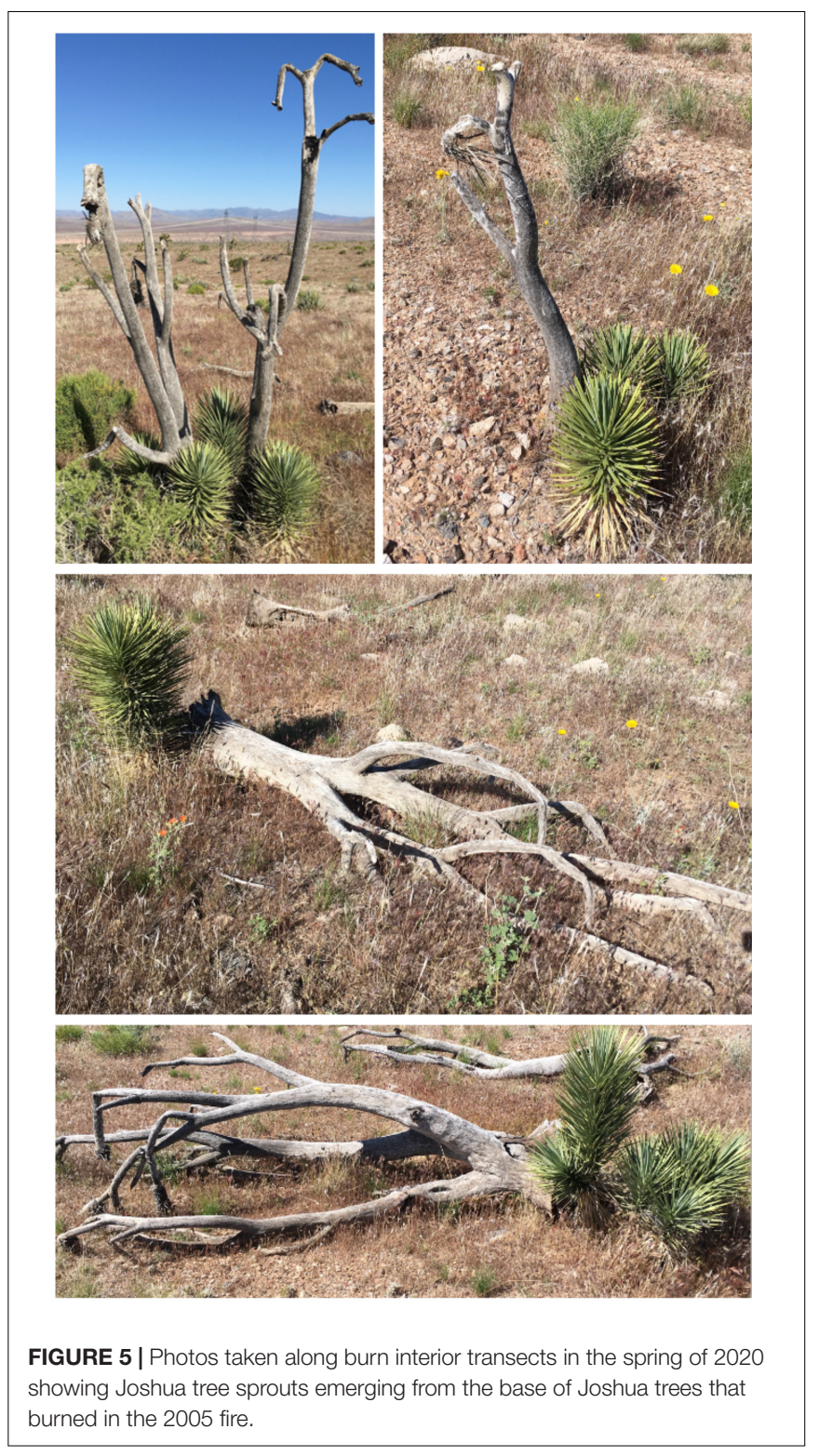

than those along burned edges (Figure 2). Burned interior transects were higher in elevation but only slightly on average (960 $\mathrm{m}$ vs. $1,050 \mathrm{~m}$ ) and elevation showed no correlation with regeneration density $\left(R^{2}=0.05, P=0.37\right)$. The literature hints at one possible hypothesis. Both Jackrabbits and gophers are known to eat regenerating Joshua trees, resulting in high mortality rates (DeFalco et al., 2010; Esque et al., 2015). Jackrabbits prefer shrubland habitat typical of the unburned transect lines and utilize burned habitats less (Knick and Dyer, 1997). This could result in lower rates of Joshua tree herbivory along burned interior transects than burned edge transects adjacent to unburned habitat where rabbits may be more active. Additional studies would need to be conducted to test his hypothesis.

Our data are consistent with previous studies showing the Joshua tree can sprout vegetatively following fire (Loik et al., 2000), but it is not a strong or consistent post-fire resprouter 
(Abella, 2010). The literature indicates that post-fire resprouting constraints on Joshua tree may be compounded by drought events (DeFalco et al., 2010) that are expected to become more frequent in the future (Abatzoglou and Kolden, 2011) and animal herbivory (Esque et al., 2015). Hotter and drier future climates are expected to physiologically contract Joshua tree's current range (Cole et al., 2011; St Clair and Hoines, 2018). In addition, extended and more severe droughts are likely to promote more fire in the Mojave Desert, causing direct mortality of Joshua trees and limiting seedling establishment by burning native nursing shrubs (Brittingham and Walker, 2000). Limiting the spread of invasive annual grasses and novel fire regimes will be critical to maintaining healthy Joshua tree populations into the future, particularly on the edge of its ecological range (Barrows et al., 2020).

\section{CONCLUSION}

Our study shows a high degree of variability in post-fire regeneration patterns of Joshua tree based on distance from burn boundaries. Joshua tree, which is thought of as a poor-post fire sprouter, especially under high burn severity (Abella, 2009; Shryock et al., 2014) did show evidence of post-fire sprouting success in our study (Figure 4). This seems especially important since we found little evidence of post-fire regeneration of Joshua tree from seed. Surprisingly, regeneration density was higher along interior transects than along burn edges although additional surveys in larger burned areas are needed to validate our findings and conclude that it is a broader geographic phenomenon in the Mojave Desert. However, additional experiments are needed to better identify the factors driving the patterns we observed. For example, monitoring of herbivory and environmental correlates such as soil resource availability and topographical variation that may contribute to variability in Joshua tree resprouting success in post-fire environments.

\section{REFERENCES}

Abatzoglou, J. T., and Kolden, C. A. (2011). Climate change in Western US deserts: potential for increased wildfire and invasive annual grasses. Rangel. Ecol. Manag. 64, 471-478. doi: 10.2111/REM-D-09-00151.1

Abella, S. R. (2009). Post-fire plant recovery in the Mojave and Sonoran Deserts of western North America. J. Arid Environ. 73, 699-707. doi: 10.1016/j.jaridenv. 2009.03.003

Abella, S. R. (2010). Disturbance and plant succession in the Mojave and Sonoran Deserts of the American Southwest. Int. J. Environ. Res. Public Health 7, 1248-1284. doi: 10.3390/ijerph7041248

Abella, S. R., Chiquoine, L. P., and Vanier, C. H. (2013). Characterizing soil seed banks and relationships to plant communities. Plant Ecol. 214, 703-715. doi: 10.1007/s11258-013-0200-3

Balch, J. K., Bradley, B. A., D’Antonio, C. M., and Gomez-Dans, J. (2013). Introduced annual grass increases regional fire activity across the arid western USA (1980-2009). Glob. Change Biol. 19, 173-183. doi: 10.1111/gcb.12046

Barrows, C. W., Ramirez, A. R., Sweet, L. C., Morelli, T. L., Millar, C. I., Frakes, N., et al. (2020). Validating climate-change refugia: empirical bottom-up approaches to support management actions. Front. Ecol. Environ. 18:298-306. doi: 10.1002/fee.2205
While we observed Joshua tree vegetative regeneration following high severity fire, regeneration densities were still dramatically lower than typical Joshua tree stands in unburned areas even 15 years after the fire (Figure 2). This suggests that post-fire vegetative sprouting alone isn't sufficient to re-establish typical stand densities in the years following fire. Since climate change is likely to increasingly constrain Joshua tree regeneration from seed (Bryant et al., 2012) management approaches that limit the establishment and spread invasive grasses and human ignitions that spread wildfire into Joshua tree stands is of high priority. Where fire does occur and Joshua tree stand re-establishment is desired, outplantings may be a restoration approach to re-establish Joshua tree stands. However, research is needed to explore the viability of this option and even then it would probably only be economically feasible at small spatial scales (Perez et al., 2019).

\section{DATA AVAILABILITY STATEMENT}

The raw data supporting the conclusions of this article will be made available by the authors, without undue reservation.

\section{AUTHOR CONTRIBUTIONS}

SeS and ES conducted the field surveys. SeS curated the data. SeS and SaS conceive the study, analyzed the data, and wrote the manuscript. ES reviewed the manuscript and provided feedback. All authors contributed to the article and approved the submitted version.

\section{FUNDING}

Brigham Young University provided funding support for this research.

Bowman, D., Balch, J. K., Artaxo, P., Bond, W. J., Carlson, J. M., Cochrane, M. A., et al. (2009). Fire in the earth system. Science 324, 481-484.

Bowman, T. R. S., McMillan, B. R., and St Clair, S. B. (2017). Rodent herbivory differentially affects mortality rates of 14 native plant species with contrasting life history and growth form traits. Oecologia 185, 465-473. doi: 10.1007/ s00442-017-3944-y

Brittingham, S., and Walker, L. R. (2000). Facilitation of Yucca brevifolia recruitment by Mojave Desert shrubs. West. North Am. Nat. 60, 374-383.

Brooks, M. L., D’Antonio, C. M., Richardson, D. M., Grace, J. B., Keeley, J. E., DiTomaso, J. M., et al. (2004). Effects of invasive alien plants on fire regimes. Bioscience 54, 677-688.

Brooks, M. L., and Matchett, J. R. (2006). Spatial and temporal patterns of wildfires in the Mojave Desert, 1980-2004. J. Arid Environ. 67, 148-164. doi: 10.1016/j. jaridenv.2006.09.027

Bryant, M., Reynolds, J., DeFalco, L. A., and Esque, T. C. (2012). Short seed longevity, variable germination conditions, and infrequent establishment events provide a narrow window for Yucca brevifolia (Agavaceae) recruitment. Am. J. Bot. 99, 1647-1654. doi: 10.3732/ajb.1200099

Cole, K. L., Ironside, K., Eischeid, J., Garfin, G., Duffy, P. B., and Toney, C. (2011). Past and ongoing shifts in Joshua tree distribution support future modeled range contraction. Ecol. Appl. 21, 137-149. doi: 10.1890/09-1800.1 
Crotteau, J. S., Varner, J. M. III, and Ritchie, M. W. (2013). Post-fire regeneration across a fire severity gradient in the southern Cascades. For. Ecol. Manag. 287, 103-112.

DeFalco, L. A., Esque, T. C., Scoles-Sciulla, S. J., and Rodgers, J. (2010). Desert wildfire and severe drought diminish survivorship of the long-lived Joshua tree (Yucca Brevifolia: Agavaceae). Am. J. Bot. 97, 243-250. doi: 10.3732/ajb. 0900032

Esque, T. C., Medica, P. A., Shryock, D. F., DeFalco, L. A., Webb, R. H., and Hunter, R. B. (2015). Direct and indirect effects of environmental variablity of growth and survivorship of pre-reproductive Joshua trees, Yucca brevifolia Englem. (Agavaceae). Am. J. Bot. 102, 85-91. doi: 10.3732/ajb.1400257

Gilliland, K. D., Huntly, N. J., and Anderson, J. E. (2006). Age and population structure of Joshua trees (Yucca brevifolia) in the northwestern Mojave Desert. West. North Am. Nat. 66, 202-208.

Horn, K. J., and St. Clair, S. B. (2017). Wildfire and exotic grass invasion alter plant productivity in response to climate variability in the Mojave Desert. Landsc. Ecol. 32, 635-646. doi: 10.1007/s10980-016-0466-7

Horn, K. J., Wilkinson, J., White, S., and St Clair, S. B. (2015). Desert wildfire impacts on plant community function. Plant Ecol. 216, 1623-1634. doi: 10.1007/ s11258-015-0546-9

Keith, S. (1982). A tree named Joshua. Am. For. 88, 40-42.

Klinger, R., and Brooks, M. (2017). Alternative pathways to landscape transformation: invasive grasses, burn severity and fire frequency in arid ecosystems. J. Ecol. 105, 1521-1533. doi: 10.1111/1365-2745.12863

Knick, S. T., and Dyer, D. L. (1997). Distribution of black-tailed jackrabbit habitat determined by GIS in southwestern Idaho. J. Wildl. Manag. 61, 75-85. doi: $10.2307 / 3802416$

Lenz, L. W. (2007). Reassessment of Yucca brevifolia and recognition of Y. jaegeriana as a distinct species. Aliso 24, 97-104. doi: 10.5642/aliso.20072401.07

Loik, M., St. Onge, C., and Rogers, J. (2000). "Post-fire recruitment of Yucca brevidolia and Yucca schidigera in Joshua Tree National Park, California," in Second Interface Between Ecology and Land Development in California. OpenFile Report 00-62, eds J. E. Keeley, M. Baer-Keely, and C. J. Fotheringham (Sacramento, CA: U.S. Geological Survey), 79-85.

Lybbert, A. H., and St Clair, S. B. (2017). Wildfire and floral herbivory alter reproduction and pollinator mutualisms of Yuccas and Yucca moths. J. Plant Ecol. 10, 851-858. doi: 10.1093/jpe/rtw077

Lybbert, A. H., Taylor, J., DeFranco, A., and St Clair, S. B. (2017). Reproductive success of wind, generalist, and specialist pollinated plant species following wildfire in desert landscapes. Int. J. Wildl. Fire 26, 1030-1039. doi: 10.1071/ WF16222

Martin, M., Girona, M. M., and Morin, H. (2020). Driving factors of conifer regeneration dynamics in eastern Canadian boreal old-growth forests. PLoS One 15:e0230221. doi: 10.1371/journal.pone.0230221
Minnich, R. (1995). "Wildland fire and early postfire succession in Joshua tree woodland and blackbrush scrub of the Mojave Desert of California," in Ancient Surfaces of the East Mojave Desert, eds R. E. Reynolds and J. Reynolds (San Bernardino CA: Museum Association Quarterly), 99-106.

Molinari, R. L., Bishop, T. B. B., Bekker, M. F., Kitchen, S. G., Allphin, L., and St Clair, S. B. (2019). Creosote growth rate and reproduction increase in postfire environments. Ecol. Evol. 9, 12897-12905. doi: 10.1002/ece3. 5771

Montoro Girona, M., Lussier, J. M., Morin, H., and Thiffault, N. (2018). Conifer regeneration after experimental shelterwood and seed-tree treatments in boreal forests: finding silvicultural alternatives. Front. Plant Sci. 9:1145. doi: 10.3389/ fpls.2018.0114

Perez, D. R., Gonzalez, F., Ceballos, C., Oneto, M., and Aronson, J. (2019). Direct seeding and outplantings in drylands of Argentinean Patagonia: estimated costs, and prospects of large-scale restoration and rehabilitation. Restor. Ecol. 27, 1105-1116.

Shryock, D. F., DeFalco, L. A., and Esque, T. C. (2014). Life-history traits predict perennial species response to fire in a desert ecosystem. Ecol. Evol. 4, 3046-3059. doi: 10.1002/ece3.1159

Soil Survey Staff (2015). Web Soil Survey. Washington, DC: Natural Resources Conservation Service.

St Clair, S. B., and Hoines, J. (2018). Reproductive ecology and stand structure of Joshua tree forests across climate gradients of the Mojave Desert. PLoS One 13:e0193248. doi: 10.1371/journal.pone.019 3248

Western Regional Climate Center (2000). Western Regional Climate Center. Tuweep, ARI: Western Regional Climate Center.

Conflict of Interest: The authors declare that the research was conducted in the absence of any commercial or financial relationships that could be construed as a potential conflict of interest.

Publisher's Note: All claims expressed in this article are solely those of the authors and do not necessarily represent those of their affiliated organizations, or those of the publisher, the editors and the reviewers. Any product that may be evaluated in this article, or claim that may be made by its manufacturer, is not guaranteed or endorsed by the publisher.

Copyright (c) 2022 St. Clair, St. Clair and St. Clair. This is an open-access article distributed under the terms of the Creative Commons Attribution License (CC BY). The use, distribution or reproduction in other forums is permitted, provided the original author(s) and the copyright owner(s) are credited and that the original publication in this journal is cited, in accordance with accepted academic practice. No use, distribution or reproduction is permitted which does not comply with these terms. 